\title{
GCLC wt Allele
}

National Cancer Institute

\section{Source}

National Cancer Institute. GCLC wt Allele. NCI Thesaurus. Code C52034.

Human GCLC wild-type allele is located within $6 \mathrm{p} 12$ and is approximately $48 \mathrm{~kb}$ in length.

This allele, which encodes glutamate-cysteine lig ase catalytic subunit protein, is involved

in the biosynthesis of glutathione. Heritable defects in the GCLC gene are associated with

hemolytic anemia (due to deficiency of gamma-glutamylcysteine synthetase) and

susceptibility to myocardial infarction. 